\title{
Record of the ocelot (Leopardus pardalis) in the state of Zacatecas, Mexico
}

\author{
Noé Pérez-Valadez \\ ${ }^{1}$ Centro Universitario de la Costa Sur, Universidad de Guadalajara. Av. Independencia nacional 151, CP. 48900, Autlán de Navarro. \\ Jalisco, México. E-mail: buteogallusanthracinus@gmail.com.
}

According to recent literature, Zacatecas is one of the States in Mexico whose mammal species are poorly studied. Matson and Baker (1986) stated that in southwestern Zacatecas mixture of subtropical valleys and adjacent highlands might be attractive to tropical felids such as the margay, jagouaroundi, and ocelot. In Mexico, the ocelot (Leopardus pardalis) is listed in the category of species endangered of extinction. In recent years, camera traps have recorded this species in northern-central States, in vegetation types that included pine-oak and oak-pine forests, but no confirmed records were previously available for the State of Zacatecas. In order to inventory the mammal species of Sierra de Nochistlan, Zacatecas, one camera trap was placed in a site where I observed animal tracks, for a period of three months, from May to August 2017. The local vegetation is an oak-pine forest. On 7 May 2017, one ocelot (Leopardus pardalis) was recorded in the oak-pine forest. Another mammal species recorded in the same site were the white-tailed deer (Odocoileus virginianus), white-nosed coati (Nasua narica), gray fox (Urocyon cinereoargenteus), and puma (Puma concolor). The closest localities where the ocelot has been recorded are Calvillo, Aguascalientes, approximately $60 \mathrm{~km}$ to the northeast, and Bolaños, Jalisco, approximately $108 \mathrm{~km}$ to the southwest. This report of the ocelot at the Sierra de Nochistlan fills the gap of the known geographic distribution of the ocelot between Jalisco and Aguascalientes. Hunting and logging are two major threats for the Sierra de Nochistlan; hence the continued efforts to further develop the biodiversity inventories will contribute to the conservation of this site, which likely represents an important biological corridor.

Trabajos recientes sobre los mamíferos de Zacatecas colocan a este estado como uno de los menos conocidos con respecto a este grupo de vertebrados. Matson y Baker (1986) mencionan que la combinación de zonas de montaña y vegetación tropical en el suroeste de Zacatecas puede ser adecuada para la presencia de felinos como el tigrillo, yaguarundi y el ocelote. El ocelote (Leopardus pardalis), es una especie catalogada en peligro de extinción en México y recientemente como resultado de fototrampeos se ha registrado en estados del centro-norte de México en bosques de pino-encino y encino-pino. Como parte de un estudio sobre diversidad mastofaunística, se instaló una cámara trampa en la Sierra de Nochistlán, al suroeste de Zacatecas. La cámara se colocó por un periodo de tres meses (mayo-agosto de 2017) en un sendero con vegetación de bosque de encino-pino donde se observaron rastros de animales. El 7 de mayo de 2017 entre las 00:45 y 00:47 horas se registró con fotografías a un ocelote (Leopardus pardalis) en bosque de encino-pino. Otras especies de mamíferos registradas en este fototrampeo fueron el venado cola blanca (Odocoileus virginianus), coatí (Nasua narica), zorra (Urocyon cinereoargenteus) y puma (Puma concolor). Los registros más cercanos a esta observación se localizan en Calvillo, Aguascalientes, aproximadamente a 60 km al noreste, y en Bolaños, Jalisco, aproximadamente a $108 \mathrm{~km}$ al noroeste. Este registro cubre un espacio donde no se tenían registros confirmados del ocelote entre los estados de Jalisco y Aguascalientes.

Key words: camera trapping; carnivores; Leopardus pardalis; ocelot; Zacatecas.

(c) 2018 Asociación Mexicana de Mastozoología, www.mastozoologiamexicana.org

\section{Introduction}

Zacatecas is one of States where mammals are poorly known, as evidenced by the recent work on this group of vertebrates (López-Ortega et al. 2012; Ríos-Muñoz et al. 2017). On the other hand, the geographical location of Zacatecas favors a number of different environments, including deserts, mountain ranges and areas with tropical vegetation (INEGI 2015). Matson and Baker (1986) mention that this combination of tropical and mountainous areas in southwestern Zacatecas may be attractive to wild feline species such as the margay (Leopardus wiedii), jaguarondi (Puma yagouaroundi) and ocelot (Leopardus pardalis). However, no records of any of these three species of felines are currently available for Zacatecas (Ríos-Muñoz et al. 2017).

In Mexico, the ocelot is a species listed as endangered of extinction in the Mexican Official Standard 059 (NOM 2010). In recent years, the known geographic distribution of this species has been extended to the states of Aguas- calientes (Valdez-Jiménez et al. 2013) and Durango (Servin et al. 2016). Camera trap images have confirmed the presence of ocelots at altitudes and vegetation types not previously reported (e. g., oak-pine forest, Iglesias et al. 2008; pine-oak forest, Ahumada-Carrillo et al. 2013).

In recent studies on the ocelot in Mexico, De la Torre et al. (2016) and Torres-Romero et al. (2017) report Zacatecas as one of the states where this species has been registered. However, the references mentioned correspond to Aguascalientes records. On the other hand, in a recent work on the mammals of Zacatecas, Ríos-Muñoz et al. (2017) reported two feline species only: puma (Puma concolor) and bobcat (Lynx rufus). Although Matson and Baker (1986) mentioned that some local inhabitants of southwestern Zacatecas have encountered small spotted cats that could match the margay or the ocelot, there were no confirmed records of these species to date. This study is the first confirmed report of the presence of the ocelot in the State of Zacatecas. 


\section{Materials and Methods}

As part of a study to gain a deeper insight into mammal diversity, a Bestok Hunting camera trap was installed in the Sierra de Nochistlan, municipality of Nochistlan de Mejia, southwestern Zacatecas (Figure 1). The camera was set to take one picture every 5 seconds, and subsequently was placed on an oak trunk at a height of approximately between 30 and $40 \mathrm{~cm}$ from the ground, in a path where animal tracks were observed. The camera was left in operation taking pictures for three months (92 days), from May to August 2017. The vegetation where the camera trap was placed corresponds to an oak-pine forest.

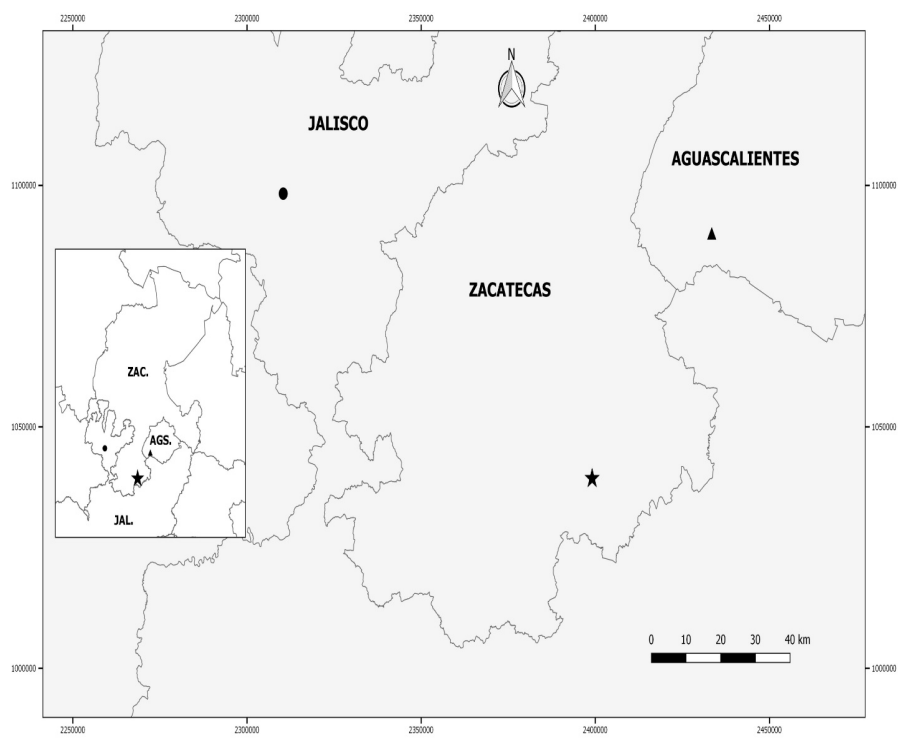

Figure 1. Map of the ocelot (Leopardus pardalis) recorded in Zacatecas (star), as well as the records closest to the study site, Calvillo, Aguascalientes (triangle) and Bolaños, Jalisco (dot)

\section{Results}

This prospection in the Sierra de Nochistlan $\left(21.3612^{\circ} \mathrm{N}\right.$, $-102.9683^{\circ} \mathrm{W}$; Figure 2) recorded five photographs of one ocelot (Leopardus pardalis) on 7 May 2017 between 00:45 and 00:47 hours, in an oak-pine forest at 2,540 masl, which is a remarkable finding for this Neotropical feline. The distance at which this specimen was photo-captured did not allow recognizing detailed features, such as sex or body status. Other mammal species recorded in this same site during the observation period were the white-tailed deer (Odocoileus virginianus), coati (Nasua narica), gray fox (Urocyon cinereoargenteus) and puma (Puma concolor).

\section{Discussion}

The record of an ocelot that is closest to the Sierra de Nochistlan, Zacatecas is located in Calvillo, Aguascalientes, approximately $60 \mathrm{~km}$ to the northeast of the study site, at 1,898 masl in a low subdeciduous forest (Valdez-Jiménez et al. 2013; Figure 1). Other close records are located in Bolaños, Jalisco, approximately $108 \mathrm{~km}$ to the northwest, where this species was recorded at two sites at 1,597 and 2,097 masl in tropical deciduous forest and pine-oak forest, respectively (Ahumada-Carrillo et al. 2013; Figure 1).

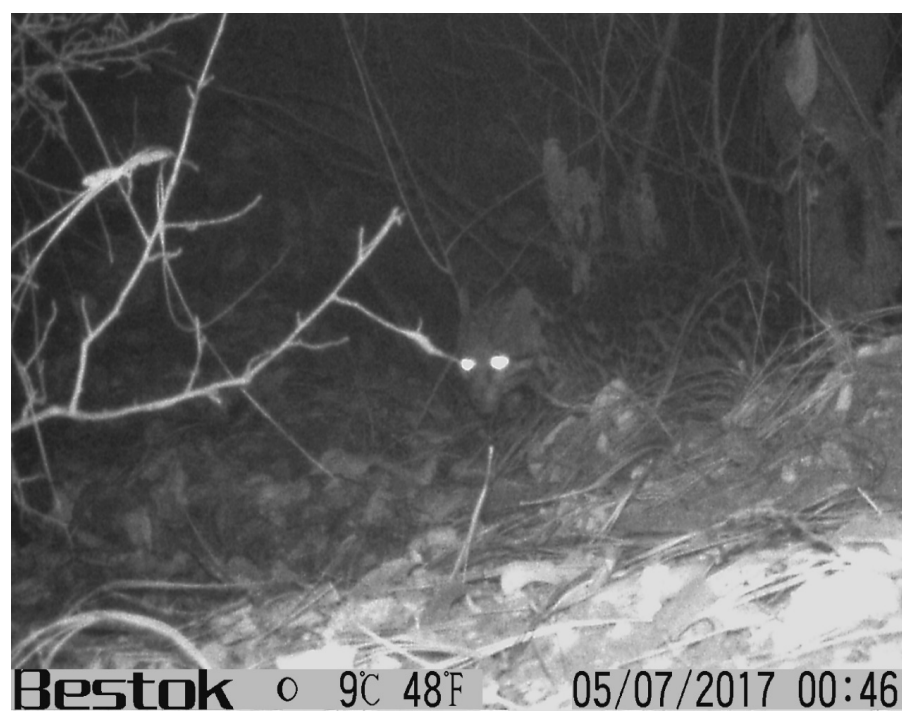

Figure 2. Photo-capture of the ocelot (Leopardus pardalis) in an oak-pine forest in the Sierra de Nochistlan, Zacatecas, Mexico.

The record of the ocelot in the southwestern region of the state of Zacatecas is outstanding, because it refers to an area between the states of Aguascalientes and Jalisco where no previous confirmed records were available. The presence of this species in this region of Zacatecas also suggests the existence of important areas that serve as biological corridors, not only for mammal species, but also of other vertebrate groups such as birds (Pérez-Valadez 2016). This corridor between the Pacific coast and the states of Jalisco, Zacatecas and Aguascalientes has also been mentioned by Valdez-Jiménez et al. (2013), who also mention reptiles in addition to birds. While there are fragments of land that show connectivity in the Sierra de Nochistlan, some forest areas have decreased due to human activities, such as hunting and illegal logging (pers. obs.), which threaten vulnerable species such as the ocelot.

\section{Acknowledgments}

I am grateful to R. C. Dowler and F. A. Reid for their assistance in the identification of ocelote photographs. María Elena Sánchez-Salazar translated the manuscript into English.

\section{Literature cited}

Ahumada-Carrillo, I. T., J. C. Arenas-Monroy, and M. A. Iñiguez. 2013. Presence of the ocelot (Leopardus pardalis) in northern Jalisco, Mexico. Revista Mexicana de Biodiversidad 84:718-721.

De la Torre, J. A., P. Arroyo-Gerala, and L. Torres-Knoop. 2016. Density and activity patterns of ocelots in the Greater Lacandona Ecosystem. Therya 7:257-269.

DIARIO OFICIAL DE LA FEDERACIÓN. 2010. Norma Oficial Mexicana NOM-059-SEMARNAT-2010, que determina las especies de flora y fauna silvestres, terrestres y acuáticas, endémicas, amenazadas, en peligro de extinción y sujetas a protección especial. Diario Oficial de la Federación. 30 de diciembre de 2010. Ciudad de México, México.

Iglesias, J., V. Sánchez-Cordero, G. Magaña-Cota, R. Bolaños, M. Aranda, R. Hernández, and F. J. Botello. 2008. Noteworthy records of margay, Leopardus wiedii and ocelot, Leopardus 
pardalis in the state of Guanajuato, Mexico. Mammalia 72:347-349.

InStituto NACIONAL de estadística y geOgRAFía. 2015. Anuario estadístico y geográfico de Zacatecas 2015. Instituto Nacional de Estadística y Geografía. Aguascalientes, Aguascalientes.

López-Ortega, G., C. Ballesteros-Barrera, Y. Acosta, and F. A. Cervantes. 2012. Los roedores de Zacatecas. Pp. 127-137 in Estudios sobre la biología de roedores silvestres mexicanos (Cervantes, F., and C. Ballesteros-Barrera, eds.). Universidad Nacional Autónoma de México, Universidad Autónoma Metropolitana. Ciudad de México, México.

Matson, J. O., AND R. H. Baker. 1986. Mammals of Zacatecas. Special Publications, Museum of Texas Tech University 24:1-88. Pérez-Valadez, N. 2016. Adiciones a la avifauna del estado de Zacatecas. Huitzil 17:175-183.

Ríos-Muñoz, C. A., D. V. Espinosa-Martínez, C. Ballesteros-Barrera, G. Ameneyro-Cruz, G. López-Ortega, J. Arroyo-Cabrales, and L. LeónPaniagua. 2017. Mamíferos de Zacatecas. Revista Mexicana de Mastozoología Nueva época 7:1-24.

Servín, J., L. E. Aguilar-Jiménez, E. F. Hernández-Reyes, J. Tinoco, And J. SÁnchez-Robles. 2016. Record of a live ocelot (Leopardus pardalis) at La Michilía Biosphere Reserve, Durango, Mexico. Western North American Naturalist 76:497-500.

Torres-Romero, E. J., E. Espinoza-Medinilla, M. A. Lazcano-Barrero, AND L. MAFFEl. 2017. Ecology and conservation of ocelot (Leopardus pardalis) in Northern Quintana Roo, Mexico. Therya 8:11-18.

Valdez-Jiménez, D., C. M. García-Balderas, and G. E. Quintero-Díaz. 2013. Presencia del ocelote (Leopardus pardalis) en la "Sierra del Laurel", municipio de Calvillo, Aguascalientes, México. Acta Zoológica Mexicana (n. s.) 29:688-692.

Associated editor: Jorge Servin

Submitted: September 12, 2017; Reviewed: November 2, 2017;

Accepted: November 12, 2017; Published on line:December 18, 2017. 
102 THERYA Vol. 9(1):99-101 